\title{
Comparison of Prophylactic Intravenous Pethidine versus Intravenous Ondansetron in Prevention Post Spinal Shivering in Hysterectomy
}

\author{
MANAL F. ABD-ELMONIEM, M.D. and RASHEDA AZZAM, M.D. \\ The Department of Anaesthiology, Intensive Care and Pain Management, Faculty of Medicine for Girls, \\ Al-Azhar University
}

\begin{abstract}
Background: Spinal anesthesia is known to significantly impair thermoregulation; shivering associated with spinal anesthesia is reported up to $55 \%$. Pethidine probably acts directly on the thermoregulatory center or via opioid receptors. Mechanism of action of 5HT antagonist as anti-shivering is thought to be related to inhibition of serotonin reuptake on the preoptic anterior hypothalamic region.
\end{abstract}

Aim of Study: This study was designed to compare the effectiveness of intravenous Pethidine versus intravenous Ondansetron for prevention of post-spinal shivering (primary outcome), hemodynamic changes, side effects of both groups were also evaluated (secondary outcome).

Material and Methods: Patients were randomly assigned allocated into two groups (Group $\mathrm{P} n=30$ patients) received pethidine $0.4 \mathrm{mg} / \mathrm{kg}$ and (Group $\mathrm{O} \mathrm{n}=30$ patients) received Ondansetron $4 \mathrm{mg}$ as premedication (each drug was mixed into $10 \mathrm{ml}$ isotonic saline and given to the patient, slowly IV).

Results: Non-significant differences between two groups as regards episodes of shivering, grading of shivering and tympanic temperature, but there is delayed onset of shivering episodes in pethdine group. There was statistically significant decrease in patients had nausea and vomiting in O group. While there was no statistically significant difference as regard sedation in both groups.

Conclusion: The use of Prophylactic 4mg Ondansetron (5HT3 antagonist) is equally effective as $0.4 \mathrm{mg} / \mathrm{kg}$ pethidine in the prevention of perioperative shivering following spinal anesthesia, maintains core temperature and Prophylactic Ondansetron also reduces the need of antiemetics.

Key Words: Pethidine - Ondansetron - Spinal anaesthesia.

\section{Introduction}

SPINAL anesthesia is known to significantly impair thermoregulation, shivering associated with spinal anesthesia is reported up to 55\% [1]. The mechanism of post spinal anesthesia shivering is

Correspondence to: Dr. Manal F. Abd-Elmoniem, E-Mail: d taha66@yahoo.co not clear, but hypothermia due to redistribution heat caused by vasodilation below the level of a neuroaxial block also by inhibiting vasoconstriction. Shivering leads to unpleasant physiological changes as increase in $\mathrm{O}_{2}$ consumption by $200-500 \%$, and increased carbon dioxide production [2], arterial hypoxemia, lactic acidosis, increased IOP and ICT and interferes with ECG monitoring, pulse rate, B.P [3]

The methods are available for the control of shivering either nonpharmacological or pharmacological. Nonpharmacological methods; as fluid warmers, maintaining ambient operating room temperature, worm blankets, surgical drapes, and active circulating water mattress have been used. Pharmacological methods; include various drugs such as opioids (pethidine, pentazocine, and tramadol), a2 agonists (clonidine, ketansarin), others such as doxapram, neofam, neostigmine, and magnesium sulfate have been tried [4] .

Pethidine probably acts directly on the thermoregulatory center or via opioid receptors. Pethidine as morphine exerts its analgesic effects by acting as an agonist on $t$-opioid receptor [5]. It also has an agonistic K-opioid receptor action, which may be involved in the anti-shivering effects it elicits [6,7].

Studies on serotonin (5-hydroxytryptamine antagonist), found it has a role in neurotransmission and thermoregulation suggest that the control of post anesthetic shivering. These 5-HT3 receptor antagonists used routinely as antiemetic and easily available and cost-effective [8]. Mechanism of action of 5HT antagonist as anti-shivering is thought to be related to inhibition of serotonin reuptake on the preoptic anterior hypothalamic region [9]. 
This study was designed to compare the effectiveness of intravenous Pethidine versus intravenous Ondansetron for prevention of post-spinal shivering (primary outcome), hemodynamic changes, side effects of both groups were also evaluated (secondary outcome).

\section{Material and Methods}

This study was a prospective, double blind, randomized, non controlled study. After the approval of the Institute's Ethics Committee and obtaining written informed consents, 60 patients of American Society of Anesthesiologists physical status I or II, aged 40-70 years, undergoing spinal anesthesia for elective hystrectomy surgeries were investigated at Al-Zahraa Hospital from January 2018 to January 2019. Patients with uncontrolled hypertension, diabetes mellitus, hepatic, pulmonary disease, thyroid disease, obesity, drug allergy, compromised cardiorespiratory conditions and patients on long term phenothiazine's and MAO inhibitors and temperature blow $36.5 \mathrm{c}$ or above $37.5^{\circ} \mathrm{C}$, were excluded from the study. Before SA, an 18 -gauge IV cannula was inserted and $15 \mathrm{~mL} / \mathrm{kg}$ normal saline the first $1 \mathrm{~h}$ and $5 \mathrm{ml} / \mathrm{kg}$ in the subsequent hours were given at room temperature (the operative room was maintained at an ambient temperature of around $22-24^{\circ} \mathrm{C}$ ). Electrocardiogram, Heart Rate (HR), noninvasive blood pressure and pulse oximetry were attached for standard monitoring, and tympanic temperature was measured. The patients were randomized into two groups of $n=30$ each using a computer generated sequence. Allocation concealment was done using sealed envelope technique. Depending on the group allocation either to receive Pethidine (Meperidine 100 $\mathrm{mg} / 2 \mathrm{ml}$-Misr Co.-Egypt) 0.4mg/kg (Group P n=30 patients) or Ondansetron 4mg (Novartis Pharma AG-Switzerland) (Group O $\mathrm{n}=30$ patients) as premedication (each drug was mixed into $10 \mathrm{ml}$ isotonic saline and given to the patient, slowly IV). SA was instituted at either L3-L4 or L4-L5 in the sitting position by the anesthetist using 22-25 gauge Quincke spinal needles (made in Tokyo, Japan) 2.5 to $3 \mathrm{~mL}$ of $5 \%$ (12.5 to $15 \mathrm{mg}$ ) hyperbaric bupivacaine was injected. SA block was assessed using pinprick and Bromage scale for the desired sensory and motor block, which was T6-T4 and Bromage scale 3 , respectively. Oxygen at $4 \mathrm{~L} / \mathrm{minute}$ was administered via a face mask, and patients were covered with drapes but not actively warmed. $10 \mathrm{mg}$ ephedrine were given if the patient became hypotensive (hypotension was defined as a decrease in MAP of $>20 \%$ fromthe baseline). I.v $0.5 \mathrm{mg}$ atropine was given if HR less than 50beat/min. Rescue i.v.
$10 \mathrm{mg}$ metoclopramide was given for vomiting episodes. Persistent pain sensation or movement of lower half was considered a failed spinal anesthesia treatment, and the patients underwent general anesthesia and were excluded from the study. Scale for shivering: Grade 0-No shivering, Grade 1-Peripheral vasoconstriction, no visible muscle activity, Grade 2-Muscular activity in one muscle group, Grade 3-Muscular activity in more than one muscle group not involving the entire body, and Grade 4-Generalized muscle activity involving the entire body [10] .

\section{Assessment parameters:}

Episodes of shivering, number of patients had shivering at 15, 30, until 120 mins after SA, grades of shivering (if shivering recurs patients were treated with additional dose Meperidine $0.3 \mathrm{mg} / \mathrm{kg}$ or Ondasetron $4 \mathrm{mg}$ in respective group). (Primary outcome). Tympanic temperature pre and after spinal, $5,10,15$ then every $15 \mathrm{~min}$ until $120 \mathrm{~min}$ after SA (Gentle temp made in China). Base line of MAP and HR before and after injection of the drugs and every 5, 10, 15min. until 120min. Complications of the drugs: As nausea, vomiting and sedation.

\section{Statistical analysis:}

Data were collected, revised, coded and entered to the Statistical Package for Social Science (IBM SPSS) Version 23. The quantitative data with parametric distribution were presented as mean, standard deviations and ranges while qualitative variables were presented as number and percentages. The comparison between groups regarding qualitative data was done by using Chi-square test and/or Fisher exact test when the expected count in any cell found less than 5. The comparison between two independent groups regarding quantitative data and was done by using independent $t$-test. The confidence interval was set to $95 \%$ and the margin of error accepted was set to $5 \%$. So, the $p$-value was considered significant at the level of $<0.05$.

\section{Results}

\section{Demographic variables:}

There was no statistically significant difference between the two groups as regarded to demographic data (age, BMI, time of operation) $p$-value $>0.05$.

\section{As regard episodes of shivering:}

There was no statistically significant difference between both groups as shown in (Table 1). 
Table (1): Episodes of shivering.

\begin{tabular}{|c|c|c|c|c|c|c|}
\hline \multirow{2}{*}{$\begin{array}{l}\text { Episodes } \\
\text { of shiverin }\end{array}$} & \multicolumn{2}{|c|}{$\mathrm{P}$ group } & \multicolumn{2}{|c|}{$\mathrm{O}$ group } & \multirow{2}{*}{$\begin{array}{c}\text { Test } \\
\text { value* }\end{array}$} & \multirow{2}{*}{$\begin{array}{c}p- \\
\text { value }\end{array}$} \\
\hline & $0 .=30$ & $\%$ I & o. $=30$ & $\%$ & & \\
\hline $\begin{array}{l}\text { Negative } \\
\text { Positive }\end{array}$ & $\begin{array}{l}25 \\
5\end{array}$ & $\begin{array}{l}83.3 \\
16.7\end{array}$ & $\begin{array}{l}25 \\
5\end{array}$ & $\begin{array}{l}83.3 \\
16.7\end{array}$ & 0.000 & 1.000 \\
\hline
\end{tabular}

$p$-value $>0.05$ : Non significant (NS).

$p$-value $<0.05$ : Significant (S).

$p$-value $<0.01$ : Highly significant (HS).

*: Chi-square test.

As regard number of patients had shivering episodes:

There was no statistically significant difference between both groups as shown in Fig. (1).

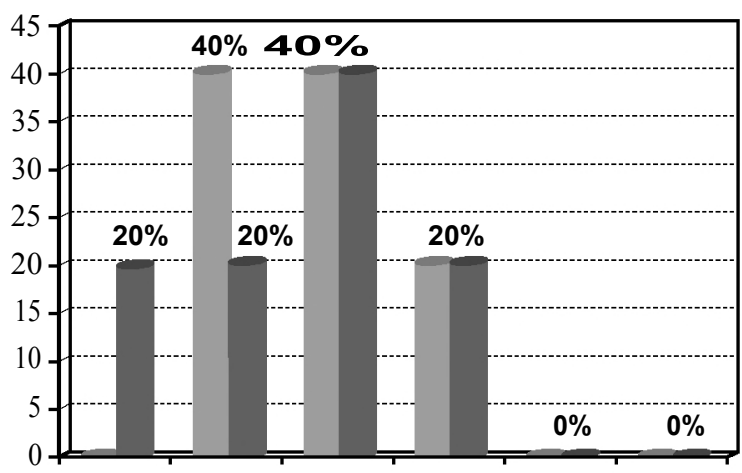

$15 \mathrm{~min}$. $30 \mathrm{~min} .45 \mathrm{~min}$. $60 \mathrm{~min} .75 \mathrm{~min} .90 \mathrm{~min}$

No. of patients had Shivering episodes

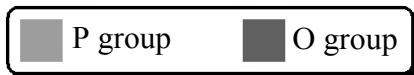

Fig. (1): Number of patients had Shivering episodes.

\section{As regard grades of shivering:}

There was no statistically significant difference between both groups as shown in (Table 2).

Table (2): Grades of shivering.

\begin{tabular}{lcccccc}
\hline Grading of & \multicolumn{2}{c}{ P group } & \multicolumn{2}{c}{ O group } & Test & $\begin{array}{c}p- \\
\text { Shivering }\end{array}$ \\
\cline { 2 - 4 } & No. & $\%$ & No. & $\%$ & & \\
\hline value* & value \\
Grade 0 & 0 & 0.0 & 0 & 0.0 & 0.000 & 1.000 \\
Grade 1 & 2 & 40.0 & 2 & 40.0 & 0.000 & 1.000 \\
Grade 2 & 2 & 40.0 & 1 & 20.0 & 0.476 & 0.490 \\
Grade 3 & 1 & 20.0 & 2 & 40.0 & 0.476 & 0.490 \\
Grade 4 & 0 & 0.0 & 0 & 0.0 & 0.000 & 1.000 \\
\hline
\end{tabular}

$p$-value $>0.05$ : Non significant (NS).

$p$-value $<0.05$ : Significant (S).

$p$-value $<0.01$ : Highly significant (HS).

*: Chi-square test.

As regard grades of tympanic membrane temperature:

There was no statistically significant difference between both groups $p$-value $>0.05$.

\section{As regard drugs complications:}

There was statistically significant decrease in patients had nausea and vomiting in $\mathrm{O}$ group. While there was no statistically significant difference as regard sedation in both groups as shown in Fig. (2).

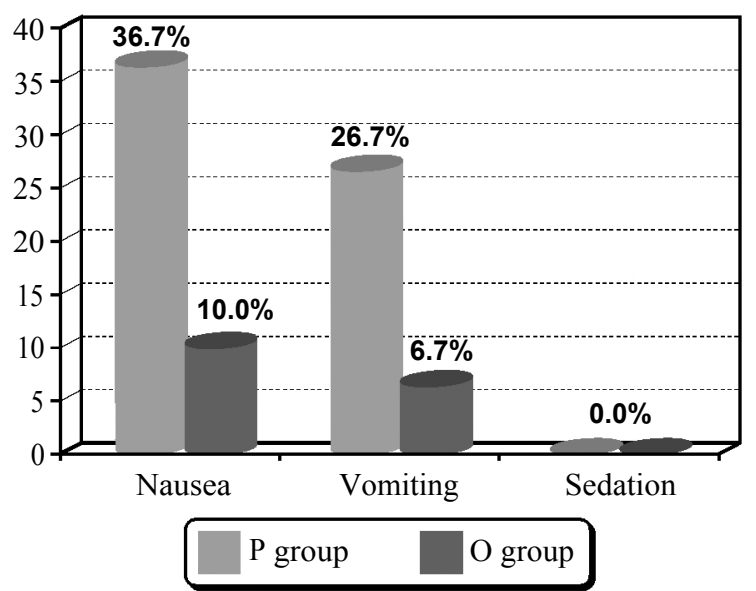

Fig. (2): Drugs complications.

As regard mean arterial blood pressure:

There was no statistically significant difference between both groups at pre spinal period, $75 \mathrm{~min}$, $90 \mathrm{~min}$ and $120 \mathrm{~min}$ post spinal. While at $5 \mathrm{~min}$, $10 \mathrm{~min}$ and $60 \mathrm{~min}$ post spinal there was statistically significant difference between both groups. Also there was highly statistically significant difference between both groups at $15 \mathrm{~min}, 30 \mathrm{~min}$ and $45 \mathrm{~min}$ post spinal as shown in Fig. (3).

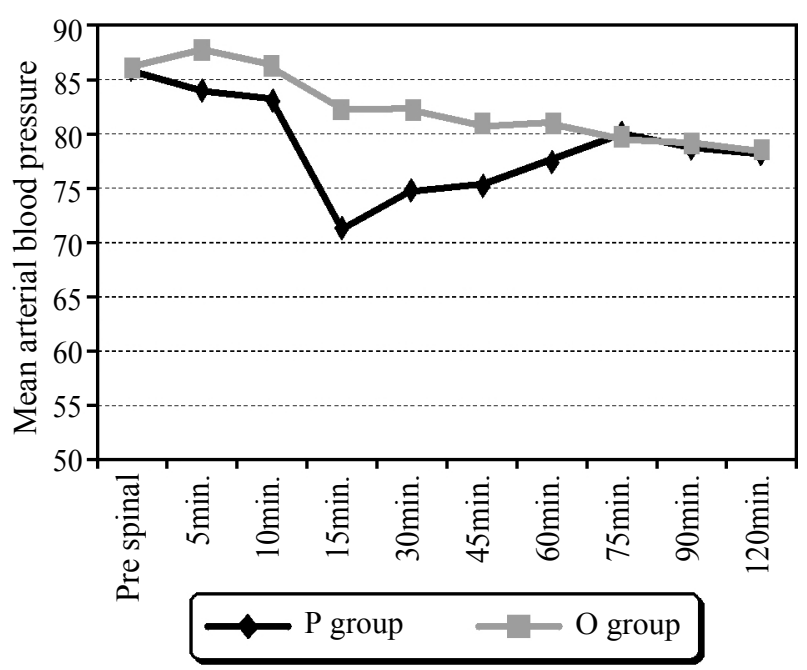

Fig. (3): Mean arterial blood pressure.

\section{As regard heart rate:}

There was no statistically significant difference between both groups as shown in Fig. (4). 


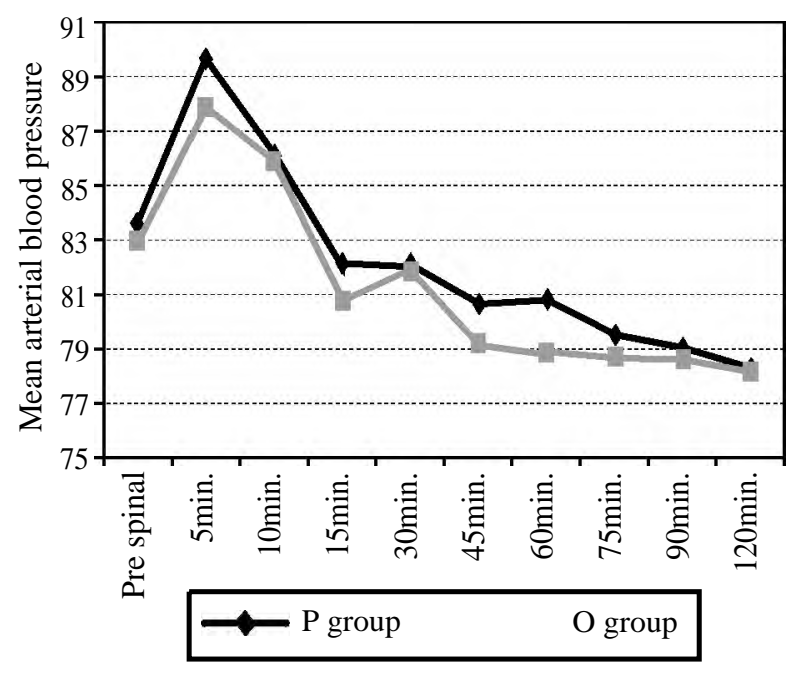

Fig. (4): Heart rate.

\section{Discussion}

Shivering an involuntary, oscillatory muscular activity, is a physiological thermoregulatory response to cold. Under spinal anaesthesia, shivering occurs as a response to lowering of core body temperature and decrease in blood supply to the upper body [11] . Factors lead to hypothermia and Shivering; age, duration of surgery, the operating room temperature, type of regional anesthesia (spinal or epidural), and infusion solution [12]. This study was designed to compare the effectiveness of intravenous Pethidine versus intravenous Ondasetron for prevention of post-spinal shivering (primary outcome), hemodynamic changes, side effects between the both groups were also evaluated (secondary outcome).

In this study we report that non-significant differences between two groups as regards episodes of shivering, grading of shivering and tympanic temperature, but there is delayed onset of shivering episodes in pethdine group.

Sajedi et al., [13], they showed that prophylactic use of granisetron $40 \mathrm{tg} / \mathrm{kg}$ is effective as meperidine $(0.4 \mathrm{mg} / \mathrm{kg})$ and tramadol $(1 \mathrm{mg} / \mathrm{kg})$ in preventing post anesthetic shivering without prolonging the emergence time from anesthesia in their prospective double-blinded study on 132 ASA I-II, patients undergoing elective orthopedic surgery under standardized general anesthesia.

These results are supported by the finding of Iqbal et al., [14], who found that the prophylactic use of iv $40 \mathrm{tg} / \mathrm{kg}$ granisetron (5HT3 antagonist) or iv $25 \mathrm{mg}$ pethidine was effective in preventing post-operative shivering.
The present study, results were also similar to the findings of Shakya et al., [15]. Who suggested that the prophylactic administration of low-dose ketamine $0.25 \mathrm{mg} / \mathrm{kg}$ and ondansetron $4 \mathrm{mg}$ produces significant antishivering effect in comparison with placebo in patients undergoing spinal anesthesia.

Chengmao et al., [10], in their meta-analysis found that 5-HT3 antagonists effectively prevent post-operative shivering after both general and spinal anaesthesia and no significant difference between the efficacy of 5-HT3 antagonists and meperidine for the prevention of shivering. Also Kabade et al., [16], found that prophylactic granisetron $40 \mathrm{tg} / \mathrm{kg}$ i.v. is as effective as pethidine $0.4 \mathrm{mg} / \mathrm{kg}$ i.v. in preventing perioperative shivering following spinal anesthesia.

Terasako and Yamamoto [17], found that Pethidine had been shown to be one of the most effective treatments to prevent post-operative shivering when they compare between pentazocine, pethidine and placebo in the treatment of postanesthetic shivering, in this study we found that episodes of shivering onset at 30min in P Group, while it was at 15min in O Group, also Park et al., [18]. Reported incidence of post-operative shivering was decreased with pethidine pre-treatment.

In other hand Eydi et al., [19], found that no case of shivering was reported in the pethidine group when he compared pethidine Vs. ketamine as post-operative management of shivering, in our result we report 5 cases of shivering, this difference may due to different numbers of sample (our sample was 30 patients) or different technique (we use pethdine as a prophylactic while Eydi et al., used it as management of shivering).

As regard changes in MAP \& HR between $P$ Group and O Group: At 5min, 10min and 60min post spinal there were statistically significant decrease in MAP in P Group, also there was highly statistically significant decrease in MAP in P Group at $15 \mathrm{~min}$, $30 \mathrm{~min}$ and $45 \mathrm{~min}$ post spinal while there were no statistically significant difference in MAP between both groups at pre spinal period, $75 \mathrm{~min}$, $90 \mathrm{~min}$ and $120 \mathrm{~min}$ post spinal. There was no statistically significant difference between both groups as regard HR.

Eldaba and Amr [20], found that administration of $1 \mathrm{mg}$ of granisetron at $5 \mathrm{~min}$ before spinal anesthesia cannot reduce blood pressure in comparison with placebo (normal saline). Moreover, they also reported that significantly lower the dosages of ephedrine and atropine in the granisetron group than those of the placebo group. 
Also Owczuk et al., [21] reported that intravenous ondansetron attenuates hypotension after SA so they advised to use ondansetron in high-risk population: As pregnant women, in whom administration of vasoconstrictors leads to decrease uterine blood flow, also elderly persons, in whom excess fluid administration increase the risk of cardiovascular decompensation.

As regard drugs complications we found that there were significant increase the incidence of nausea and vomiting in P Group than O Group, while there was no statistically significant difference as regard sedation in both groups.

Sajedi et al., [13], reported a higher incidence of nausea, vomiting, and respiratory depression, in meperidine group than granisetron group. Also the study concluded that granisetron prevent shivering, and it also reduced nausea and vomiting. Makker et al., [22], reported that in the early postoperative period both ondansetron and granisetron are equally effective in preventing post-operative nausea and vomiting in patients undergoing gynecological surgery under spinal anesthesia. On other line, Lim and Karis [23], their study reported that were no, patients developed nausea or vomiting when they compared dexmedetomidine, pethidine and tramadol in the treatment of post-neuraxial anaesthesia shivering.

\section{Conclusion:}

The use of Prophylactic 4mg Ondansetron (5 HT3 antagonist) is equally effective as $0.4 \mathrm{mg} / \mathrm{kg}$ pethidine in the prevention of perioperative shivering following spinal anesthesia, maintains core temperature and Prophylactic Ondansetron also reduces the need of antiemetics.

\section{References}

1- CROWLEY L.J. and BUGGY D.J.: Shivering and neuraxial anesthesia. Reg. Anesth. Pain Med., 33: 241-52, 2008.

2- De WITTE J. and SESSLER D.I.: Perioperative shivering: Physiology and pharmacology. Anesthesiology, 96: 46784, 2002.

3- BUGGY D.J. and CROSSLEY A.W.: Thermoregulation, mild perioperative hypothermia and postanaesthetic shivering. Br. J. Anaesth., 84: 615-28, 2000.

4- DÍAZ M. and BECKER D.E.: Thermoregulation: Physiological and clinical considerations during sedation and general anesthesia. Anesth. Prog., 57: 25-32, 2010.

5- BRYANT B. and KNIGHTS K.: Pharmacology for Health Professionals. 3 rd ed. Chatswood: Mosby Australia, [Google Scholar], 2010.
6- BRUNTON L.: Goodman and Gilman's pharmacological basis of therapeutics, 12 th ed. McGraw-Hill: [Google Scholar], 2010.

7- WRENCH I.J., CAVILL G., WARD J.E. and CROSSLEY A.W.: Comparison between alfentanil, pethidine and placebo in the treatment of post-anaesthetic shivering. Br. J. Anaesth., 79 (4): 541-2. [PubMed] [Google Scholar], 1997.

8- DEHGHANI A. and ANVARI H.M. :High dose but not low dose granisetron decreases incidence and severity of Post Anesthesia Shivering (PAS) and Post-Operative Nausea and Vomiting (PONV) following lower abdominal surgeries under spinal anesthesia. Arch. Anesth. Crit. Care, 3: 304-307, 2017.

9- MARASHI S.M., SOLTANI-OMID S., SOLTANI MOHAMMADI S., AGHAJANI Y. and MOVAFEGH A. Comparing two different doses of intravenous ondansetron with placebo on attenuation of spinal-induced hypotension and shivering. Anesth. Pain Med., 4: e12055, 2014.

10- BAYES M.X., RABASSEDA X. and PROUS J.R.: Gateways to clinical trials. Methods Find Exp. Clin. Pharmacol., 29: 697-735, 2007.

11- CHENGMAO ZHOU, YU ZHU, ZHEN LIU and LIN RUAN: 5-HT3 receptor antagonists for the prevention of postoperative shivering: A meta-analysis Journal of International Medical Research, 44 (6): 1174-81, 2016.

12- KIM H.Y., LEE K.C., LEE M.J., KIM M.N., KIM J.S., LEE W.S., et al.: Comparison of the efficacy of a forcedair warming system and circulating-water mattress on core temperature and post-anesthesia shivering in elderly patients undergoing total knee arthroplasty under spinal anesthesia. Korean J. Anesthesiol., 66: 352-7, 2014.

13- SAJEDI P., YARAGHI A. and MOSELI H.A.: Efficacy of granisetron in preventing postanesthetic shivering. Acta Anaesthesiol Taiwan, 46: 166-70, 2008.

14- IQBAL A., AHMED A., RUDRA A., et al.: Prophylactic granisetron vs pethidine for the prevention of postoperative shivering: A randomized control trial. Indian J. Anaesth., 53: 330-4, 2009.

15- SHAKYA B., CHATURVEDI A. and SAH B.P.: Prophylactic low dose ketamine and ondansetron for prevention of shivering during spinal anaesthesia. J. Anaesthesiol. Clin. Pharmacol., 26: 465, 2010.

16- KABADE S.D., VENKATESH Y., KARTHIK S. and KUMAR V.: Comparative study of granisetron versus pethidine for the prevention of perioperative shivering under spinal Anesthesia. Karnataka Anaesth. J., 2: 14, 2016.

17- TERASAKO K. and YAMAMOTO M.: Comparison between pentazocine, pethidine and placebo in the treatment of postanesthetic shivering. Acta Anaesthesiol. Scand. 44: 311-2, 2000.

18- PARK S.M., MANGAT H.S., BERGER K. and ROSENGART A.J.: Efficacy spectrum of antishivering medications: Meta-analysis of randomized controlled trials. Crit. Care Med., 40: 3070-82, 2012.

19- EYDI M., GOLZARI S.E., AGHAMOHAMMADI D., KOLAHDOUZAN K., SAFARI S. and OSTADI Z.: Postoperative management of shivering: A comparison of 
pethidine Vs. ketamine. Anesthesiol. Pain Med., 4:e15499, 2014.

20- ELDABA A.A. and AMR Y.M.: Intravenous granisetron attenuates hypotension during spinal anesthesia in cesarean delivery: A double-blind, prospective randomized controlled study. J. Anaesthesiol. Clin. Pharmacol., $31: 329$, 2015.

21- OWCZUK R., WENSKI W., POLAK-KRZEMINSKA A., TWARDOWSKI P., ARSZULOWICZ R., DYLCZYKSOMMER A., et al.: Ondansetron given intravenously attenuates arterial blood pressure drop due to spinal anesthesia: A double-blind, placebo-controlled study. Reg. Anesth. Pain Med., 33: 332-9, 2008.

22- MAKKER R., BHARDWAJ A., SINGH A.P. and ANAND A.: Comparative efficacy of ondansetron versus granisetron to prevent perioperative nausea and vomiting in patients undergoing gynaecological surgery under spinal anaesthesia. Int. J. Med. and Dent. Sci., 6: 1371-5, 2017.

23- LIM FERNA and KARIS MISIRANB: Comparison of dexmedetomidine, pethidine and tramadol in the treatment of post-neuraxial anaesthesia shivering Southern African Journal of Anaesthesia and Analgesia, 21 (1): 14-8, 2015.

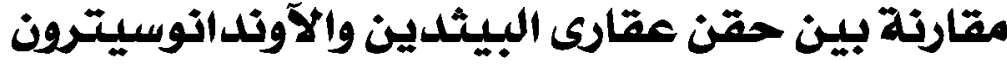

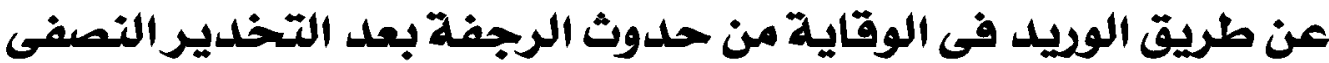 فى عمليات إستئصال الرحم الرحم لوفي
}

\author{
تعتبر الرجفة من آهم المشاكل التى تواجه المريض بعد التخدير النصفى.

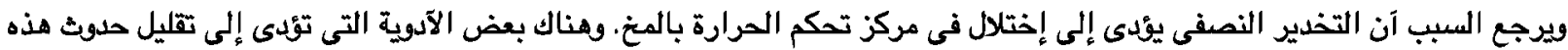

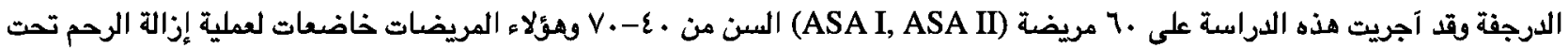 \\ تآثير التخدير النصفى وقد قسمت المريضات إلى مجموعتين (.r مريضة فى كل مجموعة). \\ • مجموعة (P) وقد آعطيت المريضات عمجم/كجم من البيشيدين قبل التخدير النصفى. \\ • مجموعة (O) وقد آعطيت المريضات عُمجم من الآوندانويسيترون قبل التخدير النصفى. \\ وقد تبين من الدراسة آن كلا من عقارى اليثيدين والآوندانوسيترون لهما القدرة على تقليل نسبة حدوث الرجفة بعد التذدير النصفى ويزيد

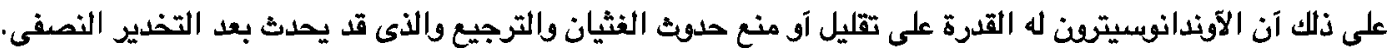

